\title{
Old Cultivars and Populations From Traditional Pepper-Growing Regions of Serbia as Breeding Potential
}

\author{
Zoran S. Ilić ${ }^{1}$, Lidija Milenković ${ }^{1}$, Mirjana Vasić ${ }^{2}$,Zdenka Girek ${ }^{3}$, Milan Zdravković ${ }^{3}$ \& Jasmina Zdravković ${ }^{3}$ \\ ${ }^{1}$ University of Priština, Faculty of Agriculture, Priština-Lešak, Serbia \\ ${ }^{2}$ Institute of Field and Vegetable Crops, Novi Sad, Serbia \\ ${ }^{3}$ Institute for Vegetable Crops, Smederevska Palanka, Serbia \\ Correspondence: Zoran S. Ilić, University of Priština, Faculty of Agriculture, Priština-Lešak, Serbia. Tel: \\ 381-63-801-4966. E-mail: zoran.ilic63@gmail.com
}

Received: March 12, 2013 Accepted: April 25, 2013 Online Published: May 15, 2013

doi:10.5539/jas.v5n6p132 URL: http://dx.doi.org/10.5539/jas.v5n6p132

\begin{abstract}
In order to collect and preserve the pepper gene fond (Capsicum annuum L.) material was collected in locations in South Serbia and Central Kosovo with long tradition of growing old pepper varieties. The area around the town of Aleksinac (villages Moravac, Prčilovac, Nozrina and Lužane) has a long tradition of growing old varieties and populations of pepper. The Žabarka and Čokotanka varieties are typical representatives hereof, and have been included in this study. From the area near the town of Leskovac (village Donja Lakošnica) we included the variety Lakošnička. This variety is very much grown here and is intended for grinding. In Central Kosovo, material was gathered in Laplje selo and Preoce, and the varieties collected were Rošajka and Bobinka crvena. These varieties have very specific colour, shape, size, aroma, intensity of heat and mode of usage. The different varieties will be stored in the Serbia Gene Bank and become valuable material in the selection and breeding of pepper in programs for obtaining varieties suitable for drying. The characteristics of the plants and fruits were studied and according to these traits grouping was done. Correlation of genotypes and traits was done by PCA (Principal Component Analysis). PCA grouped genotypes according to their traits (morphological and chemical) in two groups each. Genotypes grouped in this way represent the basic material for program of breeding pepper varieties suitable for drying. The selected varieties on the basis of superiority of characteristics can be proved a valuable material for any pepper breeding of Serbia which can be recommended for commercial cultivation.
\end{abstract}

Keywords: Capsicum annuum, old-time varieties, gene-fond, quality

\section{Introduction}

The fruit of Capsicum annuum belongs to the longum group, popularly known as red pepper. The dry fruits are used in cooking to give a mild flavour and red colour (Maiti et al., 2007). It is also high in vitamins A and C, which are important antioxidants and part of today's healthy lifestyles. Carotenoids, the largest group of plant pigments, function as antioxidants and as vitamin A precursors (Guzman et al., 2010). Vitamin C is hypothesized to prevent cancer by inhibiting the formation of nitrous compounds in the stomach, and also by stimulating the immune system (Doglin \& Yasunori, 2003). Pepper producers mostly grow newly selected varieties and hybrids of pepper, produced in Serbia or abroad. However, there are many local populations and varieties grown in yards and green gardens. The seeds of these are maintained and reproduced by local producers. They are very heterogeneous and many specific traits make them very highly valued by the consumers. Numerous specifics and magnificent adjustment to local ecological conditions make local populations very interesting for pepper breeding (Ilić et al., 1997). Many pepper varieties differ in shape, size, aroma, intensity of heat etc. Pepper fruits are usually consumed fresh or dried (as spice) but the range of application is numerous: food, pharmaceutical and cosmetic industry (Sousa et al., 2006), to name just a few. The different applications of pepper products has to have the base in corresponding variety, which suits the function of the product with its traits (Costa et al., 1989; Viana et al., 2006). The genus Capsicum consists of many varieties that are grown for their fruits, making it one of the most popular vegetables in the world. It originates from South America, including tropical and subtropical regions (Pickersgill, 1997) and represents the result of selective breeding after its domestication. It is cultivated worldwide, and has become a key element in many regional cuisines, and the selection of the autochthone genotypes has been guided by traditional fruit usage (MacNeish, 1964). Within the Capsicum genus, many breeding programs include specific 
crossing of several different varieties of Capsicum annuum. Hot and sweet pepper genotypes (Capsicum frutescens L. and Capsicum annuum L.) are very rich in genetic variability creating in this way a new, economically important variety. Traits that define a variety represent a set of a large number of traits, mostly polygene, that correlate and create the identity of a genotype (He \& Wang, 1989; Basavaraja \& Hulamani, 2001). Enrichment of the genefond by finding autochthone and domesticated genotypes represents a continuous task, together with its evaluation and characterization (Ortiz et al., 2010).

One of the primary reasons to sustain conservation of plant genetic resources in gene banks is to prevent the loss of genetic diversity (Maggioni, 2004). The main pepper collections can be found in the Russian Federation (2313), Germany (1504), France (1400) and Hungary (1400). A duplicate of the Capsicum Genetic Cooperative collection, including morphological and physiological markers, is conserved at the University of Torino, Italy. European collections hold pepper accessions originating from all over the world, as well as characterized genetic stocks and resources evaluated for disease resistance genes (Maggioni, 2004).

Systematic collection of old and local populations can be a basis for:

a) Breeding of new varieties with desirable morphological characteristics (such as intensive colour).

b) Selection towards better yield and resistance to diseases (Bezuneh, 1974).

The existing commercial assortment in Serbia (there are 40 officially registered varieties and hybrids of pepper) does not fully meet the demands of industry and contemporary vegetable production. It is therefore necessary to collect genotypes suitable for drying (for pepper powder) and for stuffing (with meat, rice, beans etc.). Breeding of new genotypes and creation of assortment for these purposes, as well as collection of old varieties are very significant tasks.

\section{Material and Method}

Within the project "South East European Development: Network on Plant Genetic Resources (SEEDNet)", and within the working group for vegetables from the Republic of Serbia, field research was conducted in order to note, register, collect, classify and evaluate old varieties and populations. The collection list and passport data were in accordance to descriptors for Capsicum genus. Five old varieties intended for traditional use (drying) were analysed:

Table 1 . The analyse of five old varieties intended for traditional use

\begin{tabular}{lll}
\hline $\begin{array}{l}\text { Local name } \\
\text { of variety }\end{array}$ & Botanical origin & Locality \\
\hline Rošajka & C. annum ssp. macrocarpum var. longum & Central Kosovo (Laplje selo, Gračanica) \\
Lakošnička & C. annum ssp. macrocarpum var. longum & South Serbia, Leskovac (Lakošnica) \\
Žabarka & C. annum ssp. macrocarpum var. dolma & Near Aleksinac (Moravac, Žitkovac) \\
Čokotanka & C. annum ssp. macrocarpum var. longum & South Serbia, from Aleksinac to Niš \\
Bobinka & C. annum ssp. microcarpum var. cerosiforme & South-east Serbia, Central Kosovo \\
\hline
\end{tabular}

\subsection{Plant Material}

The experiments were performed in an experimental garden located in the village of Moravac near Aleksinac (longitude: $21^{\circ} 42^{\prime} \mathrm{E}$, latitude: $43^{\circ} 30^{\prime} \mathrm{N}$, altitude $159 \mathrm{~m}$ ) in the central area of south Serbia. Pepper plants were produced from seedlings (sowing during mid-March and planting late May) in the open field, during 2009-2011.

All necessary crop management measures were applied: preparation of the land, fertilizing with mineral and organic fertilizers, weed, disease and pest control, inter-row tillage, irrigation and foliar nutrition. During the vegetation, morphological and biological traits of every variety - population (with the existing descriptors), yield, as well as biochemical traits (dry matter content, ash content, total sugar content of ascorbic acid and $\beta$-carotene content) were followed.

\subsection{Quality Parameters}

Total dry matter was determined by drying procedure at the temperature of $105^{\circ} \mathrm{C}$ up to the level of constant mass. Approximately $0.5 \mathrm{~g}$ of freeze-dried sample was weighed into porcelain crucibles that had previously been heated for $3 \mathrm{~h}$ at $550^{\circ} \mathrm{C}$, and the sample was converted to white ash at this same temperature for over 12-18h. 
Total and reducing sugars content was determined by the Luff-Shoorl's method, vitamin C content by Tillman's method, and carotenoid content was measured using the method based on pigment extraction by petrol- ether and pigment isolation by column chromatography, as well as by determining the colour intensity using spectrophotometric measurement.

\subsection{Data Analysis}

Correlation of genotypes and traits was determined by multi-variation technique, PCA (Principal Component Analysis) and using Statistical software: XLSTAT Version 2012.4.02 Copyright Addinsoft 1995-2012. The analysis was performed on the basis of the average values of the investigated parameters.

\section{Results and Discussion}

\subsection{Chemical Composition of Old Pepper Varieties and PCA Analysis}

Our results show that the Bobinka crvena cultivar stands out for its total content of: ash (1.03\%), vitamin C (140.8 $\left.\mathrm{mg} \cdot 100 \mathrm{~g}^{-1}\right)$ and $\beta$-carotene $(471.2 \mu \mathrm{g} / \mathrm{g} \mathrm{DM})$. Lakošnička has the highest dry matter content $(13.65 \%)$, high content of total sugars $(5.94 \%)$ as well as high level of $\beta$-carotene $\left(416.2 \mu \mathrm{g} \cdot \mathrm{g}^{-1} \mathrm{DM}\right)$, which is especially significant for drying and grinding (Table 1).

Table 1. Chemical composition of some autochthons cultivars and old populations of pepper from Serbia

\begin{tabular}{llllll}
\hline Cultivar & $\begin{array}{l}\text { Dry } \\
\text { matter } \%\end{array}$ & $\begin{array}{l}\text { Total sugar } \\
\%\end{array}$ & $\begin{array}{l}\text { Ash } \\
\%\end{array}$ & $\begin{array}{l}\text { Ascorbic Acid } \\
\left(\mathrm{mg} \cdot 100 \mathrm{~g}^{-1}\right)\end{array}$ & $\begin{array}{l}\beta \text {-karoten } \\
\left(\mu \mathrm{g} \cdot \mathrm{g}^{-1} \mathrm{D} . \mathrm{M} .\right)\end{array}$ \\
\hline Rošajka & 11.62 & 3.59 & 0.90 & 95.27 & 149.22 \\
Lakošnička & 13.65 & 5.94 & 0.84 & 98.59 & 416.70 \\
Čokotanka & 7.96 & 4.28 & 0.54 & 105.63 & 106.18 \\
Žabarka & 11.97 & 5.54 & 0.66 & 115.05 & 241.61 \\
Crvena bobinka & 13.03 & 4.03 & 1.03 & 140.84 & 471.23 \\
\hline
\end{tabular}

The first two components explain $83.23 \%$ of the variability of chemical traits of the fruit. The third main component explains $15.06 \%$, while the fourth explains only $1.72 \%$ of total variance of chemical traits.

Table 2. Traits (eigen) values and the percentage of total variance

\begin{tabular}{llll}
\hline PC & Eigen values & Percentage of variance & Cumulative (\%) \\
\hline 1 & 2.81 & 56.20 & 56.20 \\
2 & 1.35 & 27.03 & 83.23 \\
3 & 0.75 & 15.06 & 98.29 \\
4 & 0.09 & 1.72 & 100.00 \\
\hline
\end{tabular}

The content of $\beta$-carotene and dry matter are two of the most important variables building the first principal component. Total sugar content is the most significant variable of the second principal component (Table 3 ).

Table 3. The percentage share of each feature in the first four principal components

\begin{tabular}{lllll}
\hline Trait & PC1 & PC2 & PC3 & PC4 \\
\hline Dry matter & 28.83 & 5.89 & 10.68 & 35.11 \\
Total sugar & 1.23 & 67.99 & 6.13 & 0.43 \\
Ash & 25.21 & 10.26 & 20.26 & 0.63 \\
Ascorbic Acid & 12.36 & 14.26 & 59.70 & 12.28 \\
$\beta$-Carotene & 32.38 & 1.60 & 3.24 & 51.55 \\
\hline
\end{tabular}


The results in Table 3 show that the content of the ascorbic acid is the variable which is to $59.70 \%$ comprised in the third principal component. The fourth component further separates the genotypes according to dry matter and $\beta$-carotene content. The total content of sugar, ash and ascorbic acid were not correlated to other chemical traits in this study.

Based on the results in Table 2, the graphical representation of the variability of chemical properties of five pepper genotypes was based on the ratio of the first and second principal component (Figure 1).

Biplot (axes F1 and F2: 83.23\%)

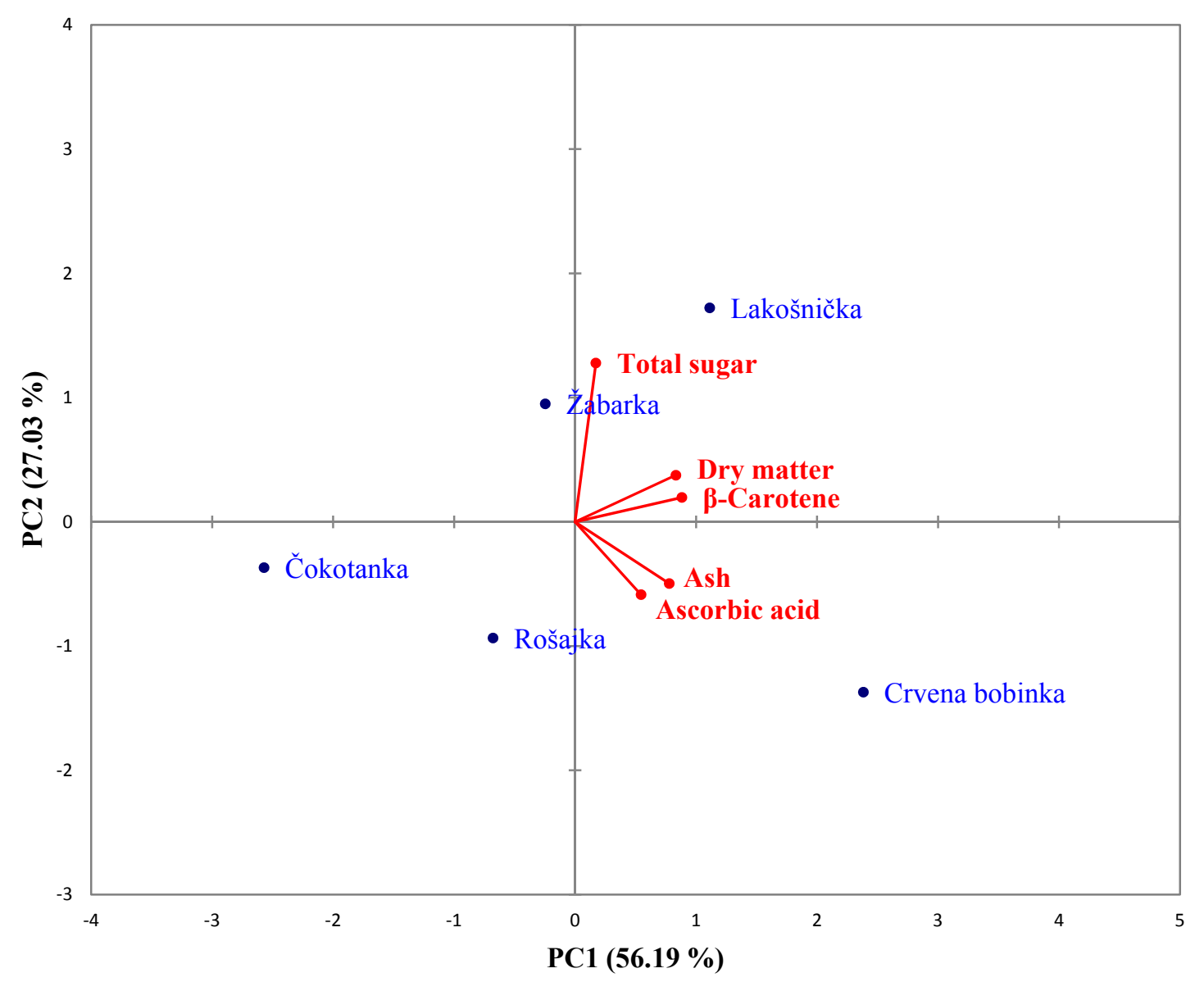

Figure 1. The relationship of the first and second principal components (PC1 and PC2) in the analysis of 5 pepper genotypes

The first principal component separates the genotypes according to dry matter content and $\beta$-carotene. The second principal component separates the genotypes according to total sugar content. Genotypes in the biplot positive side, compared to the other principal component, are characterized by high sugar content. Genotypes with high dry matter content and $\beta$-carotene are on the positive side of the biplot. Dry matter and $\beta$-carotene contents are in positive correlation. Genotypes with high dry matter content are high in $\beta$-carotene.

The genotype Lakošnička is in the positive quadrant of the biplot for PC1 and PC2, which means that it has a high content of dry matter, total sugars and $\beta$-carotene. The Žabarka genotype also has a high content of total sugars but the dry matter and $\beta$-carotene contents are lower. Bobinka crvena has the highest level of dry matter and $\beta$-carotene, but low level of total sugars.

The genotypes Čokotanka and Bobinka crvena give the largest contribution to the first principal component. These two genotypes are in negative correlation regarding two traits with the highest participation in building of the first principal component, dry matter and $\beta$-carotene contents. The largest contribution to the second principal component comes from the genotype Lakošnička with its high level of total sugar. The Rošajka genotype participated with $57.54 \%$ in building of the third principal component, while Žabarka was the most significant genotype in building of the fourth component (Table 4). 
Table 4. The percentage share of genotypes in the principal components

\begin{tabular}{lllll}
\hline Genotype & PC1 & PC2 & PC3 & PC4 \\
\hline Rošajka & 3.27 & 12.92 & 57.64 & 6.17 \\
Lakošnička & 8.82 & 43.93 & 7.17 & 20.08 \\
Čokotanka & 47.05 & 2.01 & 12.50 & 18.43 \\
Žabarka & 0.44 & 13.36 & 12.03 & 54.17 \\
Crvena bobinka & 40.42 & 27.78 & 10.66 & 1.14 \\
\hline
\end{tabular}

Varietal characteristics of interest to the general production were low capsaicin, low moisture, thin pericarp (suitable for short period of drying), uniform and concentrated maturation (facilitates the mechanical harvest), high yield and resistance to diseases, resistance to drastic temperature changes, salinity of soil and water for irrigation (Hornero-Méndez et al., 2000).

Table 5. Traits of the vegetative parts of plants

\begin{tabular}{lllll}
\hline Variety & Branching type & Growth & Plant height $(\mathrm{cm})$ & Plant width $(\mathrm{cm})$ \\
\hline Rošajka ljuta & cupped & medium & $45-55$ & $40-45$ \\
Lakošnička & cupped & medium & $40-50$ & $35-40$ \\
Venčara žabara & cupped & medium & $45-55$ & $45-55$ \\
Čokotanka & cupped & & $40-45$ & $45-50$ \\
Bobinka crvena & transient & & $40-55$ & $35-40$ \\
\hline
\end{tabular}

\subsection{Traits of Plants and Fruits (PCA Grouping)}

Čokotanka is a pepper variety with large (100-150 g) erected fruits, with 10-12 fruits per plant. The pericarp is 4-6 $\mathrm{mm}$ thick, and fruits are intended for fresh consumption and proceeding (Table 6). Rošajka has sweet and hot populations. Their common trait is nutans type of fruit. Usually, after harvesting, they are dried and used as spices.

Table 6. Fruit characteristics and yield per plant

\begin{tabular}{lllllll}
\hline Variety & Fruit shape & $\begin{array}{l}\text { Position the fruit } \\
\text { on the plant }\end{array}$ & $\begin{array}{l}\text { Number of fruits } \\
\text { per plant }\end{array}$ & $\begin{array}{l}\text { Pericarp thickness } \\
(\mathrm{mm})\end{array}$ & $\begin{array}{l}\text { Fruit weight } \\
(\mathrm{g})\end{array}$ & $\begin{array}{l}\text { Yield of the fruits per } \\
\text { plant }(\mathrm{g})\end{array}$ \\
\hline Rošajka & Hornshaped & (nutans) & $12-18$ & $2-3$ & $20-40$ & 450 \\
Lakošnička & elongated & (nutans) & $10-15$ & 2 & $50-70$ & $500-800$ \\
Žabarka & irregular & (nutans) & $7-12$ & 2 & $60-80$ & 550 \\
Čokotanka & Conical, long & (erectum) & $12-15$ & $4-6$ & $100-150$ & 1625 \\
Bobinka & Cherry-like & (seminutans) & $20-40$ & $2-3$ & $2-9$ & 180 \\
\hline
\end{tabular}

When analysing the characteristics of plants and fruits, the first two principal components comprise $89.20 \%$ of the variability properties. The third principal component explains $9.38 \%$, while the fourth explains $1.41 \%$ of total variance of plant and fruit traits (Table 7).

Table 7. Eigenvalues and the percentage of total variance

\begin{tabular}{llll}
\hline PC & Eigenvalues & Percentage of variance & Cumulative (\%) \\
\hline 1 & 3.79 & 63.17 & 63.17 \\
2 & 1.56 & 26.04 & 89.20 \\
3 & 0.56 & 9.38 & 98.59 \\
4 & 0.09 & 1.41 & 100.00 \\
\hline
\end{tabular}


Characteristics: fruit yield per plant, fruit weight and pericarp thickness were the most important variables included in the first principal component. Number of fruits per plant, plant height and width were the most important parts of the second principal component. The third principal component further branches genotypes according to fruit width, in two groups. The fourth principal component was in the best way explained by pericarp thickness (Table 8).

Table 8 . The percentage share of each feature in the first four principal components

\begin{tabular}{lllll}
\hline Trait / osobina & PC1 & PC2 & PC3 & PC4 \\
\hline Number of fruits per plant & 8.02 & 32.33 & 31.36 & 17.17 \\
Pericarp thickness & 18.01 & 10.67 & 22.45 & 28.70 \\
Fruit weight & 25.41 & 0.98 & 1.99 & 12.46 \\
Fruit yield per plant & 25.78 & 1.16 & 0.03 & 5.56 \\
Plant height & 12.73 & 26.95 & 14.39 & 18.36 \\
Plant width & 10.06 & 27.92 & 29.77 & 17.76 \\
\hline
\end{tabular}

As with the chemical properties, a figure of the properties of plants and fruits was based on a comparison of the first and second principal components (Figure 2).

Biplot (axes F1 and F2: 89.20\%)

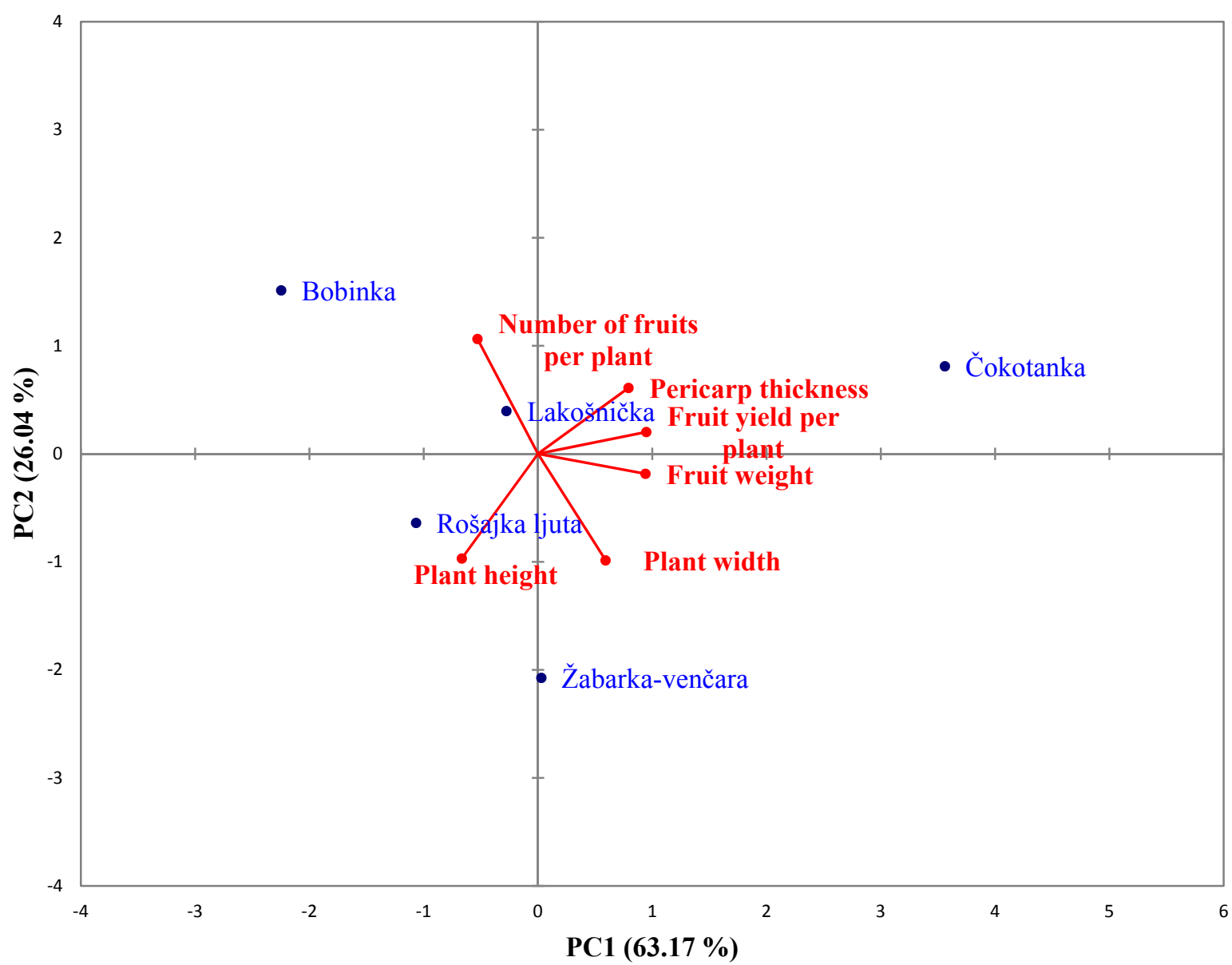

Figure 2. Ratio of the first and the second principal component (PC1 and PC2) in analysing plants and fruits of 5 pepper genotypes 
The first principal component separates genotypes according to characteristics of fruit yield per plant and fruit weight. The second principal component separates genotypes according to plant height. The plant height varies between 42.5 and $50 \mathrm{~cm}$. Genotypes on the positive side of the PC2 biplot were on average $50 \mathrm{~cm}$ high. Genotypes with higher fruit weight and higher yield per plant were located on the positive side of the biplot compared to the first principal component (Čokotanka).

The Čokotanka genotype is in the positive quadrant of the biplot for PC1 and PC2, which means that it has a high yield per plant, a higher fruit weight and an average plant height of $50 \mathrm{~cm}$. The genotype Žabarka also has an average plant height of $50 \mathrm{~cm}$, but its fruit yield per plant is 3 times lower than for the Čokotanka.

The Čokotanka genotype gives the largest contribution to the first principal component. This genotype has the highest values for fruit weight and fruit yield per plant of the genotypes studied. The Žabarka genotype, which has the largest and widest plant, gives the largest contribution to the second principal component. The Lakošnička genotype participated with $77.03 \%$ in the third principal component, while Rošajka was the most significant genotype for the fourth principal component (Table 9).

Table 9. The percentage share of the principal components of genotypes

\begin{tabular}{lllll}
\hline Genotype & PC1 & PC2 & PC3 & PC4 \\
\hline Rošajka & 6.007 & 5.253 & 1.900 & 66.840 \\
Lakošnička & 0.403 & 1.992 & 77.025 & 0.580 \\
Žabarka & 0.004 & 55.116 & 2.229 & 22.651 \\
Čokotanka & 66.936 & 8.388 & 4.463 & 0.214 \\
Crvena bobinka & 26,650 & 29,250 & 14,384 & 9,716 \\
\hline
\end{tabular}

Phenotype divergence of five varieties from the Capsicum sp. germplasm collection grown in Serbia (in regions with long tradition of pepper growing and nutrition) represents a rich source and potential for obtaining valuable recombination in pepper breeding programs (Bozokalfa et al., 2009), pepper being the economically most significant vegetable species in Serbia. This genetic potential, especially in the field of resistance to diseases and abiotic factors, as well as big range of shapes - from small and round, to large bell type shape (Zewdie et al., 1997), represents a very significant potential in selection programs regarding the morphological and chemical traits and stability in pepper production. The variation rank for most major morphological characteristics, including thickness of the pericarp and content of vitamin C is in accordance with Martinez et al. (2005). These authors also studied the capsaicin content and determined the variability, which depends on the divergence of genotype, environment influence, growing conditions, production practices and stages of maturation, which affect fruit quality traits.

The evaluation of the phenotype divergence was justified by applying PCA analysis, since the grouping can be performed according to desirable traits. For both groups of traits, morphological and biochemical, genotypes were classified in two groups of genotypes according to principal components. Bozokalfa et al. (2009) have shown that PCA analysis is suitable for grouping genotypes in Capsicum annuum $\mathrm{L}$ according to their different traits. They classified the entire collection of Turkish pepper consisting of 48 genotypes, into 7 groups. Zou et al. (2007) characterized 26 pepper genotypes using nine flower traits, classifying the Chinese genotypes in 6 groups. Portis et al. (2006) classified the 19 ecotypes originating from the Italy gene fond, which were divided into 9 clusters by using multivariate quantitative techniques. According to Lahbib (2012), the Tunisia local varieties (11) divided by 7 traits for yield and its components, were analysed with PCA and the 3 main components of variability that make up $87 \%$ of the total variance were established. Combining different multi-variation analyses to determine the divergence of pepper genotypes originating from Brazil, it was found that the thickness of the pericarp was a trait that accounted for the largest part of variance (Do Rego et al., 2003). In our study, the variance of the pericarp thickness was only $29.698 \%$ of the total variance. These results can be explained by a thin pericarp and by small differences among the researched genotypes. The studied old varieties belong to a group of pepper intended for drying (to be used as spice (powder), or for stuffing) since they have a thin pericarp.

The percentage of variation of biochemical properties of $\beta$-carotene for the fourth component (PC4) was $51.553 \%$ in this study. These properties in pepper fruits have previously been shown to be a major source of variation (Wall et al., 2001). Carotene accumulation in pepper causes a different colour in the biological maturity of the fruit. It is 
considered that the lack of the gene for capsanthin, Capsorubin synthase is a precondition for the formation of yellow pepper fruits (Hurtado-Hernandez \& Smith, 1985; Ha et al., 2007). The influence on colour of immature fruits and leaves is a combination of $\beta$-carotene and anthocyanins (Lightbourn et al., 2008). In Serbia, there are a small number of varieties that are labelled as genotypes "suitable for drying" and are therefore preserved varieties for drying and processing. They are a favourite choice for this purpose among local growers. The character and method of processing in traditional cooking defined in the fruit characteristics of different genetic constitution in some regions of Serbia.

\section{Conclusion}

A large number of tested pepper varieties differ in morphological and sensor characteristics (including colour), which determines the possibility and the mode of their usage. Not all pepper varieties can be recommended for commercial production, but must first be verified in production, through a series of agronomic and industrial demands. The greatest value of the species tested, is their high content of carotenoids, since the commercial value depends on the capacity of coloration that is directly related to the relative wealth of colours.

\section{Acknowledgements}

This study was part of the TR 31059 entitled "Integrating biotechnology approach vegetable crops for sustainable agricultural systems" and TR-31027 project entitled 'Organic agriculture - Improvement of production using fertilizers, bio-products and biological methods' financially supported by the Ministry of Science and Technological Development, Republic of Serbia.

\section{References}

Basavaraja, N., \& Hulamani, N. C. (2001). Correlation studies for quantitative characters in chilli (Capsicum annuum L.). $\mathrm{XI}^{\text {th }}$ meeting on genetics and breeding of capsicum and eggplant. Antalya, Turkey, April 9 Book of Proceedings (pp. 43-46).

Bezuneh, T. (1974). The collection and evaluation of Ethiopian pepper cultivars for use in the development of improved commercial types. ISHS Acta Horticulturae, 33, 143-148.

Bozokalfa, M. K., Eşiyok, D., \& Turhan, K. (2009). Patterns of phenotypic variation in a germplasm collection of pepper (Capsicum annuum L.) from Turkey. Spanish Journal of Agricultural Research, 7(1), 83-95.

Costa, J., Soriano, M. C., Nuez, F., \& Navarro, F. (1989). Characterization of new red pepper cultivars for grinding. Eucarpia VII ${ }^{\text {th }}$ meeting on genetics and breeding on Capsicum and Eggplant. Kragujevac, Yugoslavia, Book of Proceedings (pp. 93-96).

Do Rego, E. R., Do Rêgo, M. M., Cruz, C. D., Cecon, P. R., Amaral, D. S. S. L., \& Finger, F. L. (2003). Genetic diversity analysis of peppers: a comparison of discarding variable methods. Crop Breeding and Applied Biotechnology, 3(1), 19-26.

Doglin, Z., \& Yasunori, H. (2003). Phenolic Compounds: Ascorbic acid, Carotenoids and antioxidant properties of green, red and yellow bell pepper. Journal of Food, Agriculture and Environment, 2, 22-27.

Guzman, I., Hamby, S., Romero, J., Bosland, P. W., \& O’Connell, M. A. (2010). Variability of carotenoid biosynthesis in orange colored Capsicum spp. Plant Sciece, 179(1-2), 49-59.

Ha, S. H., Kim, J. B., Park, J. S., Lee, S. W., \& Cho, K. J. (2007). A comparison of the carotenoid accumulation in Capsicum varieties that show different ripening colours: deletion of the capsanthin-capsorubin synthase gene is not a prerequisite for the formation of a yellow pepper. Journal of Experimental Botany, 58, 3135-3144.

He, X. M., \& Wang, M. (1989). Correlation and path coefficient analysis for fruit characters in sweet pepper. Eucarpia VII ${ }^{\text {th }}$ meeting on genetics and breeding of Capsicum and Eggplant. Kragujevac, Yugoslavia. Book of Proceedings (pp. 31-35).

Hornero-Méndez, D., Gómez-Ladrón, G., R., \& Mínguez-Mosquera, I. M. (2000). Carotenoid biosynthesis changes in five red pepper (Capsicum annuum L.) cultivars during ripening cultivar selection for breeding. Agriculture Food Chemistry, 48(9), 3857-3864.

Hurtado-Hernandez, H., \& Smith, P G. (1985). Inheritance of mature fruit color in Capsicum annuum L. Journal of Heredity, 76, 211-213.

Ilić, Z., Krivošej, Z., Amiđžić, L., \& Milinčić, D. (1997). Specifies of the Old Populations and Growing Wild Vegetable Species at Kosovo and Metohija. Proceedings of the First Balkan Symposium Vegetables \& Potatoes. Acta Horticulturae, 462(2), 143-150. 
Lahbib, K., Bnejdi, F., \& El-Gazzah, M. (2012). Genetic diversity evaluation of pepper (Capsicum annuum L.) in Tunisia based on morphologic characters. African Journal of Agricultural Research, 7(23), 3413-3417.

Lightbourn, G. J., Griesbach, R. J., Novotny, J. A., Clevidence, B. A., Rao, D. D, \& Stommel, J. R. (2008). Effects of anthocyanin and carotenoid combinations on foliage and immature fruit color of Capsicum annuиm $\mathrm{L}$. Journal of Heredity, 99, 105-111.

MacNeish, R. S. (1964). Ancient mesoamerican civilization. Science, 143, 531-537.

Martinez, S., Lopez, M., Rurich, M. G., \& Alvarez, A. B. (2005). The effects of ripening stage and processing systems on vitamin content in sweet peppers (Capsicum annuum L.). International Journal of Food Science and Nutrition, 56(1), 45-51.

Maggioni, L. (2004). Conservation and use of vegetable genetic resources: A European perspective. Acta Horticulturae, 637, 13-30.

Maiti, R. K., Sarkar, N. C., Singh, V. P., \& Purohit, S. S. (2007). Research advances in capsicum - pepper (Capsicum annuum L.) and other species. Agrobios, 14, 243.

Ortiz, R., de la Flor, F., Delgado, Alvarado, G., \& Crossa, J. (2010). Classifying vegetable genetic resources-a case study with domesticated Capsicum sp. Scientia Horticultire, 126(2), 186-191.

Pickersgill, B. (1997). Genetic resources and breeding of Capsicum spp. Euphytica, 96(1), 129-133.

Portis, E., Nevro, G., Cavalanti, F., Barchi, L., \& Lanteri, S. (2006). Multivariate Analysis of Genetic Relationships between Italian Pepper Landraces. Crop Science, 46(6), 2517-2525.

Sousa, E. T., Rodrigues, F, de M., Martins, C. C., de Oliveira, F. S., Pereira, P. A. de P., \& de Andrade, J. B. (2006). Multivariate optimization and HS-SPME/GC-MS analysis of VOCs in red, yellow and purple varieties of Capsicum chinense sp. peppers. Microchemical Journal, 82, 142-149.

Viana, A. P., Pereira, T. N. S., Pereira, M. G., Souza, M. M., Maldonado, J. F. M., \& Amaral Júnior, A. T. (2006). Genetic diversity in yellow passion fruit populations. Crop Breeding and Applied Biotechnology, 6, 87-94.

Wall, M. M., Waddell, C. A., \& Bosland, P. W. (2001). Variation in $\beta$-carotene and total carotenoid content in fruits of Capsicum. Hort Science, 36, 746-749.

XL STAT Version 2012.4.02. (2012). Copyright Addinsoft 1995-2012.

Zewdie, Y., \& Zeven, A. C. (1997). Variation in Yugoslavian hot pepper (Capsicum annuum L.) accessions. Euphytica, 7, 81-89.

Zou, X., Chen, W., Zhang, Z., Dai, X., Ma, Y., Li, X., ... Li, X. F. (2007). Hayman genetic analysis of yield and quality characters in pepper ( Capsicum annuum L.). Acta Horticulturae Sinica, 34(3), 623-628. 